\title{
Urinary protein/creatinine index in follow up of patients with Wilms' tumour after nephrectomy
}

\author{
C Mpofu, J R Mann
}

\begin{abstract}
The protein/creatinine index (p/c) was determined in early morning urine (EMU) samples from available patients with Wilms' tumour who had had a nephrectomy and whose diagnosis had been made between January 1970 and December 1989. Clinical details were obtained by case note review. Results were obtained from 36 boys and 40 girls. The mean interval between nephrectomy and measurement of the EMUp/c was 9.0 years (2-23). Eleven patients had a EMUp/c greater than $20 \mathrm{mg} / \mathrm{mmol}$ (normal range less than 20). Of the 11 patients with proteinuria, there were in addition to nephrectomy other adverse features including bilateral tumours, treatment with nephrotoxic drugs, and dysplastic kidneys. Renal dysfunction seems most likely to occur where there are adverse factors in addition to unilateral nephrectomy. There was a significant correlation between the glomerular filtration rate and the EMUp/c, and it is thought that this is a simple tool which can be used for the regular monitoring of renal function in these patients.
\end{abstract}

(Arch Dis Child 1992;67:1462-6)

The high survival rate for children with Wilms' tumour has raised concern about the ability of the remaining kidney to sustain adequate renal function and allow a normal life span. The main source of concern is the growing number of reports of glomerular hyperfiltration. ${ }^{12}$ Children with Wilms' tumour invariably lose at least half of their renal mass and therefore need systematic investigation to define the extent of the problem and to identify special risk factors. The need for regular monitoring of these children's renal funtion also raises the issue of how extensively tests should be carried out during follow up.

\section{Patients and methods}

Assessment of renal function was carried out between January 1989 and December 1990 for patients receiving long term follow up for Wilms' tumour at The Children's Hospital in Birmingham. Only children whose diagnoses were made between January 1970 and December 1989 were included. Instructions were given to parents about the collection of early morning urine (EMU) samples on the morning that they were due to visit the clinic for review. Particular emphasis was placed on the need for the samples to be collected before the patient was ambulant. Urinary protein/ creatinine indices (EMUp/c) were then measured on these samples using the Coomassie blue dye-binding method. ${ }^{3}$ The upper limit of normal values for the EMUp/c has been established as $20 \mathrm{mg} / \mathrm{mmol}^{4}$ Blood pressure was measured, the diastolic pressure being taken as the point of disappearance of all sounds. Urine was also collected for culture. Estimates of the glomerular filtration rate were made, where creatinine measurements were available, from the formula height $\times \mathrm{k} /$ plasma creatinine, where $k$ is a constant whose value depends on age and sex. ${ }^{5}$ Clearance of chromium-51 labelled EDTA was determined in other patients. The subjects were divided into two groups according to the associated EMUp/c values. Renal biopsy samples were taken from two patients in view of the severity of their disease. A retrospective review of the diagnoses and management details of the patients was carried out using their case notes. The patients were all receiving unrestricted diets, with the exception of two for whom dietary protein intake had been reduced in an attempt to slow down the rate of renal deterioration. There were no documented urinary tract infections at the time of assessment.

\section{Results}

Ninety seven urine samples were obtained from 76 patients ( 36 boys and 40 girls). The mean interval from nephrectomy was $9 \cdot 0$ years (2-23 years). The mean age at nephrectomy was 3.41 years. There was no significant difference in age at nephrectomy between the patients with proteinuria and those without. In 11 patients the EMUp/c was greater than $20 \mathrm{mg} / \mathrm{mmol}$, whereas in 65 patients it was below the upper limit of normal. Sixty four (99\%) of the latter had unilateral tumours, and one $(2 \%)$ had bilateral tumours. Of those with a EMUp/c greater than $20 \mathrm{mg} / \mathrm{mmol}$, seven $(64 \%)$ had unilateral tumours and four $(36 \%)$ had bilateral tumours. All patients with a EMUp/c greater than $20 \mathrm{mg} / \mathrm{mmol}$ also had positive albustix tests. No haematuria was detected in any of the patients.

\section{RADIOTHERAPY}

A total of $42(55 \%)$ patients had received radiotherapy. Thirty one $(74 \%)$ had received radiation to the renal bed only, seven $(17 \%)$ had received radiation to the whole abdomen, two $(5 \%)$ had received radiation to the renal bed and lungs, one $(2 \%)$ had received radiation to the whole abdomen and lungs, and one (2\%) had received radiation to the lungs only. 
The median radiation dose for those children with $\mathrm{EMUp} / \mathrm{c}$ greater than $20 \mathrm{mg} / \mathrm{mmol}$ was $2820 \mathrm{cGy}$, and that for children with EMUp/c less than $20 \mathrm{mg} / \mathrm{mmol}$ was $2000 \mathrm{cGy}$. However these dose differences were not statistically significant ( $p>0.05$ by Wilcoxon rank sum test). Those patients receiving whole abdominal radiation were equally distrubuted between those with proteinuria and those without (three in each group). Only one patient with bilateral disease received radiotherapy to one renal bed after nephrectomy, but this was stopped after only one fraction (total dose $150 \mathrm{cGy}$ ).

\section{BLOOD PRESSURE}

Two patients were receiving treatment for hypertension (diastolic blood pressure persistently above the 97th centile for age and sex). These two patients had abnormal renal function and their blood pressures had been normal before the deterioration in renal function. They had had bilateral tumours, one of them also

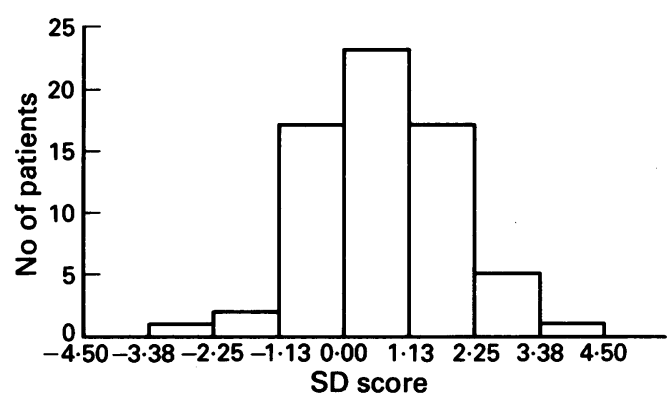

Figure 1 Frequency histogram: $S D$ scores for systolic blood pressure.

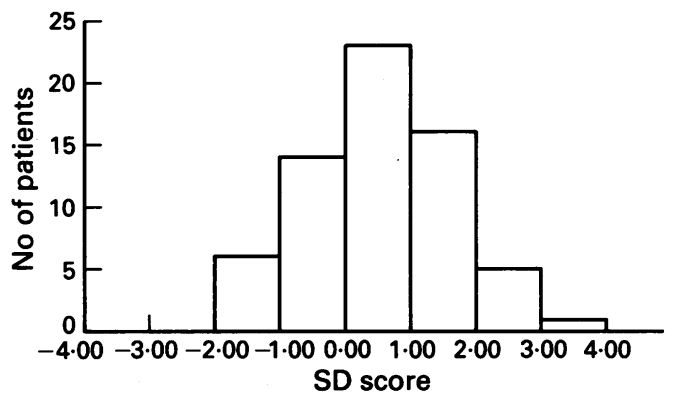

Figure 2 Frequency histogram: $S D$ scores for diastolic blood pressure.

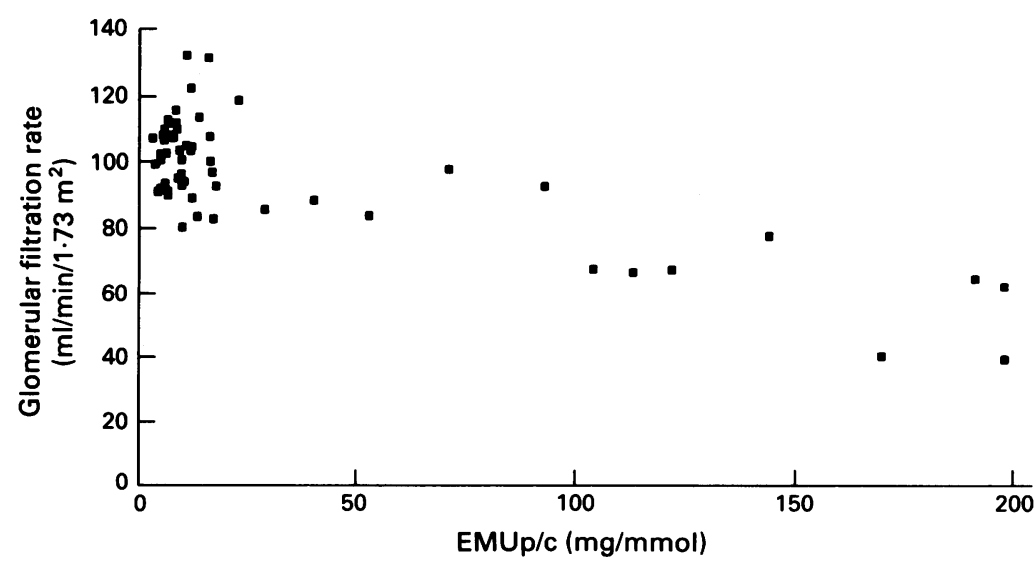

Figure 3 Correlation between glomerular filtration rate and the EMUp/c. having underlying multicystic kidney disease. The blood pressure results were expressed as SD scores. These were derived from the Report of the Second Task Force on Blood Pressure Control in Children. ${ }^{6}$ For systolic pressure the mean (SD) was $0.72(1.29)$ (median 0.77). For diastolic pressure the mean (SD) was $0.48(1 \cdot 14)$ (median 0.54 ) (figs 1 and 2).

\section{URINARY TRACT INFECTIONS}

Nine patients had recorded urinary tract infections. Five had a EMUp/c less than 20 $\mathrm{mg} / \mathrm{mmol}$ and four had a EMUp/c greater than $20 \mathrm{mg} / \mathrm{mmol}$. Only one of these patients had recurrent infections; all the others were single episodes that were successfully treated.

\section{GLOMERULAR FILTRATION RATE}

Results of glomerular filtration rate estimations were available from 55 patients. Only four of these were obtained from chromium-51 labelled EDTA clearance measurements; the rest were estimated from serum creatinine concentrations. Forty six patients had a EMUp/c less than 20 $\mathrm{mg} / \mathrm{mmol}$ and nine greater than 20 . No patient had a glomerular filtration rate less than $80 \mathrm{ml}$ $\mathrm{min} / 1.73 \mathrm{~m}^{2}$ in the group with a EMUp/c less than $20 \mathrm{mg} / \mathrm{mmol}$, and their mean glomerular filtration rate was $104.51 \mathrm{ml} / \mathrm{min} / 1.73 \mathrm{~m}^{2}$ (96.01-132-35). In those patients with a EMUp/c greater than $20 \mathrm{mg} / \mathrm{mmol}$, three $(33 \%)$ had a glomerular filtration rate less than $80 \mathrm{ml} / \mathrm{min} /$ $1.73 \mathrm{~m}^{2}$ ) (mean 88.66 (39-121.6)). The mean (range) intervals between nephrectomy and glomerular filtration rate results were 3.36 $(0 \cdot 1-11 \cdot 02)$ years and $9 \cdot 52(1 \cdot 6-22 \cdot 2)$ years for those with a EMUp/c less than and greater than $20 \mathrm{mg} / \mathrm{mmol}$ respectively. There was a significant correlation between the EMUp/c and glomerular filtration rate (Pearson's correlation coefficient -0.61 ) (fig 3). The glomerular filtration rate of the five patients with bilateral tumours are shown in table 1 .

\section{CHARACTERISTICS OF PATIENTS WITH A EMUP/C} $>20$ MG/MMOL

Table 2 summarises the main features of those 11 patients with abnormal renal function. Their mean age at nephrectomy was 2.42 years. Compared with 3.59 years for the 64 patients with a EMUp/c less than $20 \mathrm{mg} / \mathrm{mmol}$. This difference was not significant. Four of the patients were severely affected (EMUp/c >80 $\mathrm{mg} / \mathrm{mmol}$ ) and three of these had bilateral tumours. Of the seven patients with less severe proteinuria (EMUp/c 20.3-28.9 mg/mmol), only one had bilateral tumours. This patient's values

Table 1 Glomerular filtration rate for children with bilateral Wilms' tumour

\begin{tabular}{lcc}
\hline Patient No & $\begin{array}{l}\text { Glomerular } \\
\text { filtration } \\
\text { rate }\left(\mathrm{ml} / \mathrm{min} / 1 \cdot 73 \mathrm{~m}^{2}\right)\end{array}$ & $\begin{array}{l}\text { EMUp/c } \\
(\mathrm{mg} / \mathrm{mmol})\end{array}$ \\
\hline 1 & $39 \cdot 0$ & $>20$ \\
2 & $61 \cdot 7$ & $>20$ \\
3 & $97 \cdot 2$ & $>20$ \\
4 & $116 \cdot 5$ & $>20$ \\
5 & $115 \cdot 5$ & $<20$ \\
\hline
\end{tabular}


Table 2 Characteristics of children with a EMUp/c greater than $20 \mathrm{mg} / \mathrm{mmol}$

\begin{tabular}{|c|c|c|c|c|c|c|c|c|c|}
\hline $\begin{array}{l}\text { Patient } \\
\text { No }\end{array}$ & $\begin{array}{l}\text { Site of } \\
\text { tumour }\end{array}$ & $\begin{array}{l}\text { Operation } \\
\text { performed }\end{array}$ & Chemotherapyt & Radiotherapy & $\begin{array}{l}\text { Other } \\
\text { characteristics }\end{array}$ & $\begin{array}{l}\text { Age at } \\
\text { nephrectomy } \\
\text { (years) }\end{array}$ & $\begin{array}{l}\text { No of } \\
\text { urinary } \\
\text { tract } \\
\text { infections }\end{array}$ & $\begin{array}{l}\text { Interval } \\
\text { between } \\
\text { nephrectomy and } \\
\text { measurement } \\
\text { (years) }\end{array}$ & $\begin{array}{l}\text { EMUp/c } \\
(\mathrm{mg} / \mathrm{mmol})\end{array}$ \\
\hline $\begin{array}{l}1 \\
2 \\
3\end{array}$ & $\begin{array}{l}\text { Bilateral } \\
\text { Bilateral } \\
\text { Bilateral }\end{array}$ & $\begin{array}{l}\text { CU } \\
\text { BPN } \\
\text { BPN }\end{array}$ & $\begin{array}{l}\text { VAC } \\
\text { AVA } \\
\text { AVA }\end{array}$ & $\begin{array}{l}\text { Renal bed } \\
=\end{array}$ & $\begin{array}{l}\text { Polycystic } \\
\text { Polycystic } \\
\text { aniridia; } \\
\text { Wilms' } \\
\text { pyelonephritis }\end{array}$ & $\begin{array}{l}1 \cdot 1 \\
2 \cdot 0 \\
1 \cdot 7\end{array}$ & $\begin{array}{l}1 \\
1 \\
\text { Recurrent }\end{array}$ & $\begin{array}{r}22 \\
5 \\
12\end{array}$ & $\begin{array}{r}198 \\
42 \\
170\end{array}$ \\
\hline 4 & Bilateral & UN & $\begin{array}{l}\text { AVA } \\
\text { VICA }\end{array}$ & Whole lung & - & $2 \cdot 4$ & 1 & 3 & 43 \\
\hline 5 & Unilateral & UN & $\begin{array}{l}\text { AVA } \\
\text { VIC }\end{array}$ & $\begin{array}{l}\text { Renal bed, } \\
\text { pelvis }\end{array}$ & - & $1 \cdot 9$ & - & 13 & 40 \\
\hline $\begin{array}{l}6 \\
7\end{array}$ & $\begin{array}{l}\text { Unilateral } \\
\text { Unilateral }\end{array}$ & $\begin{array}{l}\text { UN } \\
\text { UN }\end{array}$ & $\begin{array}{l}\text { VCR } \\
\text { AVA } \\
\text { VI }\end{array}$ & $\begin{array}{l}\text { Whole abdomen } \\
\text { Whole abdomen, } \\
\text { pelvis }\end{array}$ & - & $\begin{array}{l}3 \cdot 4 \\
7 \cdot 0\end{array}$ & $\overline{-}$ & $\begin{array}{r}14 \\
5\end{array}$ & $\begin{array}{l}27 \\
93\end{array}$ \\
\hline 8 & Unilateral & UN & AV & - & $\begin{array}{l}\text { Dysmorphic } \\
\text { syndrome }\end{array}$ & $2 \cdot 7$ & - & 5 & 29 \\
\hline $\begin{array}{r}9 \\
10\end{array}$ & $\begin{array}{l}\text { Unilateral } \\
\text { Unilateral }\end{array}$ & UN & $\begin{array}{l}\text { AVA } \\
\text { AVA }\end{array}$ & - & $\begin{array}{c}\text { Toxic gentamicin } \\
\text { concentrations }\end{array}$ & $\begin{array}{l}1 \cdot 7 \\
1 \cdot 5\end{array}$ & $\overline{-}$ & $\begin{array}{l}16 \\
15\end{array}$ & $\begin{array}{l}56 \\
22\end{array}$ \\
\hline 11 & Unilateral & UN & AV & Whole abdomen & 一 & 0.8 & - & 16 & 23 \\
\hline
\end{tabular}

*UN=unilateral nephrectomy; $B P N=$ bilateral partial nephrectomy; $C U=$ complete nephrectomy and contralateral partial nephrectomy. $+\mathrm{VAC}=$ vincristine, actinomycin, and cyclophosphamide; AVA=actinomycin, vincristine, and Adriamycin; VICA= vincristine, ifosfamide, and carboplatin;
$\mathrm{VIC}=$ vincristine, ifosfamide, and cisplatin; $\mathrm{VI}=$ vincristine and ifosfamide; $\mathrm{AV}=$ actinomycin and vincristine; VCR=vincristine.

for the EMUp/c have steadily decreased from 52 to $20.3 \mathrm{mg} / \mathrm{mmol}$.

There were four patients with bilateral tumours necessitating extensive surgery. One of these patients had unilateral multicystic renal dysplasia and the other had bilateral multicystic renal dysplasia and the aniridia-Wilms' tumour syndrome, recurrent urinary tract infections, and histological evidence of chronic pyelonephritis. The other patient's renal biopsy sample showed widespread interstitial fibrosis, tubular atrophy, marked glomerular enlargement, and hilar arteriolar thickening with intramural hyaline deposits. Two of 11 glomeruli were globally sclerosed, with no focal segmental sclerosis being identified. These findings probably represented the results of previous irradiation with changes of glomerular hyperfiltration superimposed. The biopsy samples had been taken in view of the severity of these patient's renal disease. Another of these four patients also received ifosfamide $\left(10.8 \mathrm{~g} / \mathrm{m}^{2}\right)$, carboplatin $\left(733.3 \mathrm{mg} / \mathrm{m}^{2}\right)$, and whole lung irradiation for pulmonary relapses. Only one patient in this group received renal radiation (150 cGy). Of the remaining seven patients (unilateral tumours), two had Beckwith's syndrome. They received whole abdominal radiation (2250 and $3000 \mathrm{cGy}$ ), one of them also receiving ifosfamide $\left(60 \mathrm{~g} / \mathrm{m}^{2}\right)$ for a recurrence of the tumour. Another patient with a recurrence of the tumour received treatment that included ifosfamide $\left(60 \mathrm{~g} / \mathrm{m}^{2}\right)$ and cisplatin $\left(300 \mathrm{mg} / \mathrm{m}^{2}\right)$. One patient received whole abdominal radiation, another received acyclovir for chickenpox prophlyaxis and toxic concentrations of gentamicin during treatment of fever and neutropenia. One patient had a familial syndrome of mental retardation and hypotonia. In the remaining patient no additional features were identified. A total of three patients has received nephrotoxic drugs, making it impossible to determine the correlation between drug dose and degree of proteinuria. None of the patients with normal protein excretion had received nephrotoxic drugs.

\section{Discussion}

One of the earliest studies of renal function in survivors of Wilms' tumour was carried out by Mitus et $a .^{7}$ It focused on the role of radiotherapy to the remaining kidney and calculated the dose of radiation using the known scatter of radiation from the old orthovoltage machines. They concluded that at doses greater than 1200 cGy there was significant kidney damage. Barrera et al found that only two of 16 children had mild proteinuria. ${ }^{8}$ They had normal glomerular filtration rates, were normotensive, and radiotherapy was not found to be important in the aetiology of the proteinuria. Two studies have been published suggesting that renal function is normal for most survivors of unilateral Wilms' tumour. In the study by Bhisitkul et al, ${ }^{9}$ renal functional reserve was found to be normal in 12 survivors of unilateral Wilms' tumour (follow up 9-23 years) and their matched controls. This was determined by measurement of creatinine clearance before and after an acute protein load by mouth. They concluded that for up to 15 years after nephrectomy for unilateral Wilms' tumour there was no evidence of hyperfiltration injury. In the study by Makipernaa $e t$ al four of 30 subjects had a subnormal kidney length and five had hypertension. ${ }^{10}$ Tubular function was normal, and albumin excretion was greater than $20 \mathrm{mg} / 24$ hours in three subjects. No correlation was established between albuminuria and treatment modalities. The follow up time for this study was 11-28 years. There have, however, been case reports of children with congenital single kidneys who have subsequently developed serious renal impairment. Thorner et al reported three children with single kidneys who developed persistent proteinuria and deterioration in the glomerular filtration rate. ${ }^{11}$ All had renal biopsy samples showing focal segmental glomerulosclerosis. In another report two children treated for Wilms' tumour at 3.5 and 18 months of age developed persistent proteinuria and glomerulosclerosis, ${ }^{12}$ one of them requiring a kidney transplant at 21 years of age. 
In our study we used the protein/creatinine index in early morning urine samples as an indicator of renal function, and only carried out more detailed assessment in those patients with abnormal results. Support for this approach can be found in animal and human studies. Provoost et al carried out work on rats in which they assessed the effect of various levels of dietary protein on renal function in nephrectomised and non-nephrectomised rats. ${ }^{13}$ Examination of their curves for glomerular filtration rate and urinary protein excretion shows that proteinuria preceded the decrease in glomerular filtration rate. A similar approach was taken by Milford $e t$ $a l .{ }^{14}$ In their study of children with diarrhoea associated haemolytic uraemic syndrome, they found a strong correlation between the level of protein excretion and renal function. Barratt $e t$ al also observed that significant glomerular disease could be present in the absence of any changes in glomerular filtration rate measurements. ${ }^{15}$ The measurement of proteinuria therefore provides a method of detecting glomerular disease at an early stage and a way of monitoring its course and response to treatment. Assessment of proteinuria can be carried out simply and reliably by measurement of the protein:creatinine ratio in single urine samples, ${ }^{1617}$ the effect of exercise and the upright posture being eliminated by using early morning urine. ${ }^{4}$

The results of our study show that 10 of 11 of the patients with an abnormal EMUp/c had adverse factors in addition to nephrectomy contributing to impaired renal function. This finding is supported by another study of patients undergoing nephrectomy in childhood. ${ }^{18}$ The significance of the syndrome of mental retardation, dysmorphism, and hypotonia in relation to renal function remains unclear, however. The presence of bilateral tumours was clearly associated with the subsequent development of proteinuria (four of five such patients), the common feature being a loss of large proportions of kidney tissue. The most severely affected patients were those with bilateral tumours (three of four), the less severely affected having unilateral tumours (six of seven). In addition to this two of the severely affected patients had underlying renal abnormalities that could themselves have led to endstage renal failure (multicystic dysplastic kidneys), and one subsequently received ifosfamide and carboplatin (nephrotoxic drugs). Although we have no biopsy material, it is well known that Beckwith's syndrome is associated with renal disease. ${ }^{19}$ The two patients with this syndrome had received whole abdominal radiation and one had also received ifosfamide, so they had multiple reasons for the development of impaired renal function.

The one patient with no obvious factors in addition to nephrectomy could have impaired renal function due to glomerular hyperfiltration. This has been described in several studies on unilaterally nephrectomised rats $^{12} 20$ and the underlying pathology is identified as focal segmental glomerulosclerosis. Other studies have shown glomerular hyperfiltration in children and young adults with diabetes mellitus. ${ }^{21-23}$ Morita et al, ${ }^{24}$ in their study of renal biopsy samples from children and adults with reflux nephropathy, found a strong positive correlation between the percentage of glomeruli showing focal segmental glomerulosclerosis and the severity of proteinuria $(r=0.89 ; \mathrm{p}<0.0001)$. The two renal biopsy samples showed chronic pyelonephritis in one and early changes of glomerular hyperfiltration in the other.

Our study found that most $(86 \%)$ of the children surviving Wilms' tumour had a normal renal function. Impaired renal function was found in $10 \%$ of patients with a unilateral Wilms' tumour (seven of 71 ), and $80 \%$ with bilateral tumours (four of five). Bilateral tumours clearly pose a high risk of developing impaired renal function. Pre-existing renal abnormality, whole abdominal radiation, and the use of nephrotoxic drugs provided extra risk factors for those patients with unilateral and those with bilateral tumours. The age at nephrectomy was lower for patients with reduced renal function compared with those whose renal function was normal, though this difference was not statistically significant. Other studies have also found similar results. ${ }^{25} 26$ We consider that the use of the protein/ creatinine index in early morning urine samples, with measurement of blood pressure, is a simple way of monitoring these patients. Our current practice is to perform a baseline determination of the EMUp/c on completion of treatment and annually thereafter as long as results are normal. When abnormal results are obtained the patients are referred to the nephrology department for further evaluation and management.

To understand more clearly the natural course of renal function after nephrectomy for Wilms' tumour longitudinal studies over prolonged periods of time are needed. It is planned to carry out such studies in our centre, and these will include measurements of blood pressure, renal mass, and function, and storage of urine samples should allow future measurement of proteins not currently measurable.

This study was supported by the Leukaemia Research Fund. We also thank Dr F Raafat (Department of pathology, Birmingham Children's Hospital) and Professor R H R White (Department of nephrology, Birmingham Children's Hospital) for allowing us to nephrology, Birmingham Children's Hospital) for allowing us to quote their opinions on the renal biopsy samples, and Dr C M preparation of this paper.

1 Brenner BM, Meyer TW, Hostetter TH. Dietary protein intake and the progressive nature of kidney disease: the role of hamodynamically mediated glomerular iniury in the of haemodynamically min the pathogenesis of progressive glomerular sclerosis in aging, 1982;307:652-9.

2 Hostetter TH, Olson JL, Rennke HG, Venkatachalam MA Brenner BM. Hyperfiltration in remnant nephrons: a
BMatetter TH, Olson JL, Rennke HG, Venkatachalam MA, potentially adverse response to renal ablation. Am F Physiol 1981;241:F85-93.

3 Bradford $M M$. A rapid and sensitive method for the quantitation of microgram quantities of protein utilizing the prin ciple of protein-dye binding. Ann Biochem 1976;72:248-54.

4 Elises JS, Griffiths PD, Hocking MD, Taylor CM, White RHR. Simplified quantitation of urinary protein excretion in children. Clin Nephrol 1988;30:225-9.

5 Schwartz GJ, Brion LP, Spitzer A. The use of plasma creatinine concentration for estimating glomerular filtration rate in infants, children, and adolescents. Pediatr Clin North Am 1987;34:571-90.

6 Report of the Second Task Force on Blood Pressure Control in Children. Pediatrics 1987;79:1-25.

7 Mitus A, Tefft M, Fellers FX. Long term follow-up of renal 
functions of 108 children who underwent nephrectomy tor malignant disease. Pediatrics 1969;44:912-21.

8 Barrera M, Roy LP, Stevens M. Long-term follow-up after unilateral nephrectomy and radiotherapy for Wilms' unilateral nephrectomy and radiother

9 Bhisitkul DM, Morgan ER, Vozer MA, Langman CB. Renal functional reserve in long-term survivors of Wilms' tumour. functional reserve in long-ter

10 Makipernaa A, Koskimies O, Jaaskelainen J, Teppo AM, Siimes MA. Renal growth and function 11-28 years after treatment of Wilms' tumour. Eur $\mathcal{F}$ Pediatr 1990;150: 444-7.

11 Thorner PS, Arbus GS, Celermajer DS, Baumal R. Focal segmental glomerulosclerosis and progressive renal failure associated with a unilateral kidney. Pediatrics 1984;73: 806-10.

12 Welch TR, McAdams AJ. Focal glomerulosclerosis as a late sequela of Wilms' tumour. $\mathcal{F}$ Pediatr 1986;108:105-9.

13 Provoost AP, De Keijzer MH, Molenaar JC. Effect of protein intake on life long changes in renal function of rats unilaterally nephrectomized at a young age. $f \mathrm{Lab}$ Clin Med 1989;114:19-26.

14 Milford DV, White RHR, Taylor CM. Prognostic significance of proteinuria one year after onset of diarrheacance of proteinuria one year after onset of diarrhea-
associated hemolytic-uremic syndrome. $\mathcal{F}$ Pediatr 1990;118: associated

15 Barratt TM, McLaine PN, Soothill JF. Albumin excretion as a measure of glomerular dysfunction in children. Arch Dis Child 1970;45:496-501.

16 Ginsberg JM, Chang BS, Matarese RA, Garella S. Use of single voided urine samples to estimate quantitative proteinuria. N Engl Y Med 1983;309:1543-6.

17 Houser $M$. Assessment of proteinuria using random urine samples. $\mathcal{F}$ Pediatr 1984;104:845-8.

18 Robitaille P, Lortie L, Mongeau J, Sinnassamy P. Long-term follow-up of patients who underwent unilateral nephrectomy in childhood Lancet 1985;:1297-9.

19 Mulvihill DM, Mercado M, Boineau FG. BeckwithWiedemann syndrome and its association with type III polycystic kidney disease. Pediatr Nephrol 1989;3:286-9.

20 Shimamura T, Morrison AB. A progressive glomerulosclerosis occurring in partial five-sixths nephrectomized rats. $A m \mathcal{F}$ Pathol 1975;79:95-101.

21 Schwartz M, Ditzel J. Abnormality increased glomerular filtration rate in short-term insulin treated diabetic subjects. Diabetes 1967;16:264-7.

22 Mogensen CE. Renal function changes in diabetes. Diabetes 1976;25:872-9.

23 Christiansen JS, Frandsen M, Parving H-H. The effect of intravenous insulin infusion on kidney function in insulindependent diabetes. Diabetologia 1981;20:199-204.

24 Morita M, Yoshiara S, White RHR Raafat F. The glomerular changes in children with reflux nephropathy, $\boldsymbol{F}$ Pathol changes in childret

25 Aperia A, Broberger O, Wikstad I, Wilton P. Renal growth and function in patients nephrectomized in childhood. Acta Paediatr Scand 1977;66:185-92.

26 Boner G, Shelp WD, Newton M, Rieselbach RE. Factors influencing the glomerular filtration rate in the remaining kidney of transplant donors. Am $\mathcal{J}$ Med 1973;55:169. 